\title{
4
}

\section{Budget reform in China: Progress and prospects in the Xi Jinping era}

Christine Wong

\section{Introduction}

After three decades of remarkable growth and development in the country, the Chinese leadership is confronted with a very different set of challenges to those faced by its predecessors at the outset of its marketoriented reform program. China then was a poor but relatively welleducated and egalitarian country, with an abundance of surplus labour in the rural sector and very little interaction with the global market. A series of measures to increase the scope of the market and facilitate the transfer of labour from agriculture to industry was all it took to launch China's economic lift-off. Now, China is an upper- to middle-income country with emerging shortages of manual labour that dominates the global supply of low to mid-end manufactured goods and global demand for most commodities. The traditional model of extensive growth dependent on exports and investment, however, appears to be running out of steam.

The administration of President Xi Jinping has acknowledged that a major shift is required by announcing a new era of 'comprehensively deepening reforms', which was endorsed at the Third Plenum of the Chinese Communist Party's Eighteenth Congress in November 2013. The 60-point 'Decision of the Chinese Communist Party Central Committee on Several Major Questions about Deepening Reform' (Xinhua 2013) 
spelled out an ambitious, comprehensive agenda containing 336 reform initiatives under 16 broad headings that cover all parts of the economy, society, the political system and its institutions. Together, the measures are aimed at restructuring the roles of government and the market, with modernising governance the ultimate goal of the program.

The Third Plenum Decisions (TPD) identified fiscal reform as a key priority. Writing in the Communist Party journal Qiushi, Finance Minister Lou Jiwei explained that China's fiscal system has not kept up with the needs of the growing and increasingly complex economy:

$[T]$ he defects have become increasingly apparent: the budget management system is not standardized, transparent, or suited to the requirements of modern governance; the tax system ... is not conducive to supporting the shift to the new development paradigm, ${ }^{1}$ social fairness, or market integration. The division of responsibilities between the central and local governments is unclear and unreasonable ... These problems ... affect not only the stability and sustainability of the fiscal system itself, they also [adversely] affect the national development strategy and the effectiveness of macroeconomic policy. (Lou 2014) ${ }^{2}$

Lou (2014) argued that, 'in this round of reform, small patches and fixes will no longer suffice', and fundamental reform of the fiscal system is needed to build the foundation to support the modernisation of governance called for by the TPD.

Fiscal reforms have led the way in the TPD reforms, with many measures and initiatives rolled out in quick order. In June 2014, the Politburo approved the 'Overall Program for Deepening Reform of the Fiscal System', authorising comprehensive reform of that system. In August 2014, the Standing Committee of the National People's Congress approved the revised Budget Law (BL), which sets out provisions mandating numerous changes and, for the first time, authorises local governments to borrow for capital investments (NPC Standing Committee 2014).

Working at the compressed pace set out in the TPD, which called for the entire reform program to be implemented by 2020, Minister Lou announced at a press conference in mid-2014 that the first phase of reform would focus on budget and public financial management (PFM)

1 As early as 2002, the government announced its goal of shifting to a development paradigm that promotes services and consumption in place of industry and investment (Wong 2010).

2 Translated by the author. 
reforms, phase two would begin in 2015 with a focus on reforms of the tax system and phase three would begin in 2016 and would focus on intergovernmental fiscal reform (Han et al. 2014).

This chapter examines the state of the budget in China today and reviews the proposed reforms of PFM to offer a preliminary assessment of their prospects. The rest of the chapter is organised as follows: section two reviews the fiscal reforms implemented in the 1990s through to the first decade of the current century. Section three discusses the current situation and the proposed reform program for PFM. Section four provides a preliminary assessment of the program's prospects and a brief conclusion.

\section{The fits and starts of fiscal reforms through to 2010}

The first major reform of the fiscal system was enacted in 1994, when a new system of taxes was introduced, centring on the value-added tax (VAT), a business tax, a corporate income tax, a personal income tax and several taxes on property, land transactions and land use. These are broadbased taxes with uniform levy rates. They replaced the previous complex system, with its hundreds of product-specific industrial-commercial taxes transplanted from the Soviet economic system, and began to separate government finances from those of state-owned enterprises (SOEs) by introducing an income tax on profits to replace the previous negotiated profit remittances. While the new tax system was far from perfect, it represented a huge improvement in terms of simplifying the tax structure, eliminating distortionary elements and increasing transparency, and it greatly facilitated tax administration and the monitoring of tax capacity across regions. Along with the creation of a new national tax administration, this system restored the government's revenue mechanism and reversed the steep fiscal decline that had characterised the first two decades of market reform (Wong and Bird 2008). ${ }^{3}$

3 As in other former planned economies, in China, the budget went into steep decline when market reforms eroded the 'pillars' of the government revenue mechanism: state monopoly over industrial ownership, administratively fixed prices favouring industry and compulsory procurement and delivery of raw materials. At its trough in 1996, China's budget was 11 per cent of gross domestic product (GDP) — one-third the level under the planned economy (Wong and Bird 2008). 
Under the planned economy, the budget was not a significant policy instrument. It was simply the financial counterpart to the economic (physical) plan in which the government's allocative decisions were embedded. Budget preparation simply followed the plan, and financial performance was of secondary importance. Even as the budget gained increasing importance when the planned economy and its allocative instruments were gradually phased out in the 1980s and 1990s, the government was slow to recognise the urgent need to install a PFM system to manage its finances, as all attention was focused on finding a way to revive the revenue mechanism.

PFM reform began finally in 1999, when the government introduced a broad package over the following three to four years that included reforms to budget preparation, budget classification, treasury management, government procurement and the installation of new fiscal information systems (Wong 2005). New procedures were introduced for budget preparation and approval, and budget reporting to the National People's Congress was strengthened. Departmental budgets were introduced alongside the traditional functional allocations (e.g. appropriations for 'education' were distributed to all ministries and agencies with responsibility for education and training), aimed at clearly identifying all resources and expenditures for each government department as the first step towards building a system whereby spending units could be held accountable for the public monies they received.

A single treasury account was created to manage the government's cash receipts and payments. To support treasury reform and improved budgeting, the Ministry of Finance began work on a new government financial information management system. A new budget classification system was rolled out in 2006 to improve the tracking of expenditure by functional categories. Standardised procedures for government procurement were introduced to improve cost efficiencies and reduce the scope for corruption, adopting many of the procedures of international organisations for tendering large-scale purchases of equipment and services. With these reforms, China had begun to put in place the basic infrastructure for a modern system of budget management, but the real work was just starting. Many of the reform measures require extensive training and information dissemination so they can be put in place, with full implementation often taking a decade or more. In China, the biggest task was to ensure implementation of the reforms at the subnational level, where 85 per cent of China's public expenditure takes place. 
By 2004-05, however, it appeared that these reforms in PFM had stalled across the board. From the outside, it is hard to know exactly why this happened, but a compelling narrative can be put together from the macroeconomic trends over this period to show that reform efforts were likely overwhelmed by the sheer size of the ramp-up in public expenditure.

In economic growth terms, the first decade of the twenty-first century was a golden era for China. Joining the World Trade Organization had opened up wider access to global markets, and China rode the exceptionally buoyant global trade and investment conditions to achieve double-digit growth rates in per capita GDP. Even when the Global Financial Crisis (GFC) hit in 2007, and while much of the world struggled through years of recession and stagnation in its wake, thanks to its massive stimulus program, China continued to race ahead with only a brief slowdown in 2009. As a result, per capita GDP growth averaged an astonishing 13.2 per cent per annum during 2000-12. ${ }^{4}$

During this growth spurt, government revenue grew even faster, at an annual rate of 22 per cent! By mid decade, the government's coffers were overflowing and the government spent lavishly. This fitted well with the populist stance adopted by the government from 2003 onwards, when then president $\mathrm{Hu}$ Jintao and premier Wen Jiabao came into office vowing to rebalance public spending to improve services, and, in particular, to 'tilt' in favour of rural areas to reduce their shortfall in provision. Under the banner of a 'harmonious society', adopted at the Fourth Plenum of the Sixteenth Communist Party Central Committee in September 2004, Beijing began to pump resources into expanding the social safety net to include rural citizens and improving the provision of social services (Wong 2010).

Many new programs were introduced with central government subsidies, including reform of rural fees, free rural education, rural cooperative medical schemes, income support for farmers under the rural minimum living stipend scheme (dibao) and the universal rural pension (World Bank 2007). Lin and Wong (2012) counted the introduction of no fewer than 12 programs of subsidies that were aimed directly at farming families between 2001 and 2007, from subsidies for seed and farm machinery to subsidies for crop insurance and household appliances.

4 Unless otherwise noted, all growth calculations are in real terms after deflating by the consumer price index (CPI). 
Typically, the programs began modestly, but were often ratcheted up rapidly as more revenue became available. For example, free rural education began in 2001 as a small program providing subsidies to finance free textbooks and offset school fees and boarding subsidies for children from impoverished households in designated poor counties. It was unexpectedly expanded in 2006 to cover all school fees for all students in rural primary and middle schools (Brock et al. 2008). Likewise, the rural health insurance scheme started in 2003 with an annual subsidy of RMB20 (A \$3.75), which grew 15-fold within a decade to RMB300 (A \$56) for each of the program's more than 800 million participants.

Many of these 'harmonious society' programs are huge: the provision of free rural education covers some 140 million students; at its peak, the rural cooperative medical scheme had more than 830 million participants; and the universal rural pension scheme has a potential beneficiary pool of more than 800 million people. ${ }^{5}$ These programs have made huge additions to budgetary expenditure at the county level, which is the level of government responsible for the provision of rural services, such as agricultural services, education, health care, social welfare and pensions. As a result, the vertical share of total national budgetary expenditures at the county level rose from 26 per cent to 43 per cent during 2000-10, compared with just 18 per cent for the central government. On the ground, this means that an 'average' county has seen its budget grow tenfold within a decade, from RMB200 million (A $\$ 37.3$ million) to RMB2 billion (A $\$ 373$ million) by $2010 !^{6}$

\section{Sleepwalking into a quagmire}

A salient feature of the policies of the $\mathrm{Hu}-$ Wen administration was that they were implemented with no adjustment to the central-local government revenue-sharing arrangements. Instead, all the burden of financing was put on the use of transfers. During that decade, central government transfers to local governments grew from 2.4 per cent

\footnotetext{
5 Premier Wen Jiabao cited a figure of 835 million participants in the rural health insurance scheme (new cooperative medical scheme [NCMS]) in his work report to the National People's Congress in 2011. This is much larger than the number of rural residents, but many migrant workers were enrolled in the NCMS as they were ineligible for urban schemes. In recent years, many NCMS programs have been merged with a similar urban basic medical scheme.

6 Figures are in nominal renminbi, based on estimated shares of revenue by tier of government. This was equal to average growth of nearly 24 per cent per annum in nominal terms, or 21 per cent per annum in real terms.
} 
of GDP, in 2000, to 7.7 per cent, even as GDP itself grew fourfold. Moreover, in China's fiscal system, these transfers have to be passed down level by level-from Beijing to the provinces, from provinces to municipalities and from municipalities to counties. The administrative burden of managing the proliferation of new programs and the rapidly growing transfers to fund them must have created an extraordinary strain on the bureaucracy at all levels. Studies such as those by Wong (2010) and Lin and Wong (2012) have pointed to the government's lack of capacity to monitor and evaluate the programs as a constraint on achieving desired policy outcomes, citing problems that ranged from poor program design to coarse financial management and unresponsive services. While many benefits have accrued from the new programs, they were also marred by wastefulness, program capture, cost inflation and even the creation of 'ghost teachers' and 'ghost schools', among other things. Another likely side effect of this onslaught of new programs and new monies raining down from higher levels was that efforts to implement reform were shunted aside as everyone just tried to cope with the flows.

The neglect of institutional reform over the past decade was even more damaging in the cities (Wong 2013a, 2013b). Since market reforms began 35 years ago, people have flocked to China's cities. As the country's urbanisation rate rose from 20 per cent to more than 50 per cent of the total population, more than 500 million new residents have been added to urban areas. During the decade 2000-10 alone, the urban population grew by 210 million.

Around the world, governments struggle with the task of providing infrastructure and public services in the course of urbanisation (Bahl et al. 2013). In China, amid the steep and prolonged fiscal decline in the 1980 s and 1990s, the government had few resources to devote to the needs of urbanisation. Instead, political leaders tolerated and indeed encouraged the use of informal, backdoor practices that enabled cities to obtain the resources needed, and China's municipalities therefore came to rely overwhelmingly on extra-budgetary resources (Wong 2009, 2013a). With rapid urbanisation pushing up the price of land, land quickly became the biggest source of extra-budgetary revenue. In recent years, receipts from land sales ${ }^{7}$ have accounted for one-third to one-half of all revenue for firstand second-tier cities. ${ }^{8}$

7 Strictly speaking, landownership remains with the state, but the right of use can be sold.

8 Estimates from Wong (2013a). 
To finance the infrastructure needed to support urban growth (such as schools, public transport and other urban facilities), Chinese citieslike their counterparts around the world-also borrowed money. Since they were, until the recent change, prohibited from direct borrowing, cities borrowed off-budget, through quasi-public financial entities set up as enterprises under government departments. These local investment corporations (LICs) — variously named City X Development Corporation-undertook the coordination and financing of the construction of facilities such as water supply, sewerage, roads and utility hook-ups. Typically, they raised and bundled together bank loans and other financing, using a variety of municipal assets, including budgetary and off-budget revenue, as equity and collateral, with land playing a principal role in providing the financing as well as the collateral (Wong 2013a).

This extra-budgetary financing from land sales and off-budget borrowing developed largely outside the purview of government financial oversight. ${ }^{9}$ While it helped greatly to expand the financial resources available and was instrumental in enabling the dynamic urbanisation that took place over the past two decades, it also sowed the seeds for some of the most intractable problems facing Xi Jinping's administration today. The symbiotic relationship between land sales and LICs led inexorably to the overuse of both, resulting in excessive land takings, urban sprawl and the creation of excess capacity in industry as cities competed for jobcreating investment to raise land values. And the easy access to money from land sales and LICs also led inexorably to wasteful and inefficient investments and even ghost cities, along with graft and corruption on an unprecedented scale.

\section{The current reform program}

Paradoxically, then, even as it appears that China has reached the pinnacle of economic success after a decade in which it claimed a number of worldbeating accomplishments_-becoming the world's largest manufacturer in 2008, the largest exporter in 2010 and passing Japan in 2012 to become the second-largest economy behind the United States-the view from

9 For an early account of how the central government was kept largely in the dark about the development of LICs and the extent of local government borrowing, see Wong (2011). 
the top leadership is that the country is facing unprecedented challenges. The program of sweeping reform endorsed by the Communist Party Congress in November 2013 was a manifestation of that view.

Many of the provisions in the revised BL and associated documents are aimed at correcting the problems just described to rein in local government debt, tp rein in extra-budgetary revenue and to regain macroeconomic oversight of fiscal resources, improve budget transparency and strengthen accountability by, among other things, providing better legal foundations and oversight by the National People's Congress. The BL also sought to improve the efficiency and efficacy of intergovernmental transfers by specifying the principles and objectives for their establishment and their budgeting methodology, as well as the timing of provision (BL, Articles 16, 38 and 52). To limit the use of earmarked transfers, the BL emphasises the need to conduct regular appraisals and set exit mechanisms for them.

In a press conference just after passage of the BL, Lou Jiwei (2014) explained that one of the key provisions in the law states that budget management should be comprehensive: '[a]ll revenue and expenditures of government should be included in the budget' (Article 4) and government expenditures must include all government activities, including local government debt. Also, this comprehensive budget must be supervised by the People's Congress. To combat corruption, Lou noted, the new $\mathrm{BL}$ emphasises budget transparency, to stem the problem at the source. For the first time, the $\mathrm{BL}$ makes comprehensive provisions for budget openness, with clear rules on the scope, timing and specifics of disclosure requirements for key items such as transfer payments, government debt and departmental budgets for public agencies (Article 14). It also specifies legal liabilities for the breach of these budget disclosure norms (Article 92).

Among the most important provisions in the $\mathrm{BL}$ is the authorisation given to provincial governments to borrow-although under tight supervision by the central government as well as the provincial People's Congress. Under a call to 'open the front door, lock the back door and build walls around it', the BL stipulates that local governments must report on the purpose, size and mode of debt, along with specifying the mechanisms of supervision and legal liabilities (Articles 35 and 94). The BL was followed a month later by the issuance of 'State Council Document 43', which laid 
out an ambitious plan to tackle the stock of existing debt and a structure for managing local government borrowing, starting with separating LICs from local government finance. ${ }^{10}$

In this first phase of reform, all efforts are focused on PFM and regaining control over the budget and allocative processes. It is only in phase three that reforms will turn to addressing issues with the intergovernmental fiscal system. This sequencing makes sense in light of the severity of the problems of local government debt and the extent of extra-budgetary financing. The progress of these reforms, however, may be hindered by some potential sources of resistance. I will note just three below.

The first and most immediate source of resistance is the effort to shut off bank lending to LICs and move it into the more transparent and regulated channel of debt issuance, which is seen as an important step towards bringing local debt under control and regaining fiscal discipline. The dilemma is that, in recent years, local governments have grown reliant on land revenue and LICs to finance public infrastructure at very robust levels, and these investments have been a big part of China's investmentdriven growth dynamic. Weaning local governments off these sources of finance will force them to deleverage- a necessary step for rebalancing the economy, but one that risks setting off a fiscal crunch as local governments cut back on investment. The on-again, off-again clampdown on LICs in the past three years has already helped to deflate the housing market and significantly raised the threat of defaults since local governments and LICs are perilously dependent on land sales to service their debt. Unease with the slowing growth has already led to some provisions of the reform being reversed. On 15 May 2015, the State Council ordered banks to continue lending to LICs that have projects under construction, substantially reversing the earlier edict (Anderlini 2015).

Effective PFM requires that the budget is comprehensive and includes all fiscal revenue, expenditures and liabilities. In the past, PFM reform efforts had focused only on the budget execution aspects of financial management-expenditure control, treasury, accounting and procurement - and paid insufficient attention to debt and financial risks, especially at the subnational level. The current reform aims to fix this gap, and the new BL and 'State Council Document No. 63' that followed in December laid down a mandate for governments at all levels to compile

10 See Naughton (2015) for a brief discussion of Document 43 and how it is designed to work. 
and release to the public a comprehensive government financial report to include not only on-budget revenue, expenditures and direct debts, but also a balance sheet of government assets and liabilities and a statement of cash flows.

The new government financial reporting system (GFRS) is to provide an accurate and comprehensive reflection of government financial outcomes, as a basis for strengthening public resource management, increasing efficiency and guarding against fiscal risks. The new GFRS will be built on modified accrual accounting rules and will have greatly expanded coverage in both reporting entities and contents. It will be far more demanding of the bureaucracy and will require many methodological changes. Some of the changes will likely affect the relationship between government and the reporting entities in fundamental ways, starting with the selection and classification of entities, which moves budget reform into politically contentious territory.

Under the principle that government finance reporting must include all entities that have material impact on the government's fiscal position (IMF 2014), all SOEs_-including LICs—-must be included. The exclusion of SOEs has long been a blind spot in budget reporting in China given that their financial interaction with government has remained fluid and fuzzy, especially at the local level. The SOE sector is huge. Nationwide, there are hundreds of thousands of SOEs; in 2013, more than 18,000 large ones had annual revenue of more than RMB20 million (A $\$ 3.7$ million) from their main activity. ${ }^{11}$ They had assets totalling RMB34 trillion (A \$6.3 trillion) and were distributed across all provinces. In Beijing alone, there were 790 of these large SOEs, with assets of RMB2.3 trillion (A $\$ 429$ billion) and debts of RMB1.2 trillion (A $\$ 224$ billion) (NBS 2014: Table 13.1). Given the size and potential impact on government finances of SOEs, reform to include them in government accounting is long overdue. Resistance to letting go of SOEs has made SOE reform among the slowest-moving components of President Xi's reform program, and the effort to incorporate SOEs in budget reporting is more likely to be bogged down than to act as a spur to the much-needed debate on statemarket relations.

11 These are classified as 'above-scale' enterprises (NBS 2014). 
Finally, given the highly decentralised pattern of public expenditure in China, for which the central government accounts for only 15 per cent, PFM reform depends critically on its implementation at the subnational level. As PFM reforms aim to curb extra-budgetary resources and activities, they are seen as depriving local governments of autonomy, and will be met with much foot-dragging. The experience of the 1990s is not encouraging, when the take-up of new PFM processes was slow and uneven at subnational levels. More than 15 years after the first round of PFM reform called for increasing transparency and the adoption of uniform reporting standards, for example, information on local budgets remains spotty and uneven, and few provinces release information on transfers to lower levels (Wong 2013a). In China's hierarchical but delegated system of level-by-level administration, the central government has only attenuated control over subordinates.

In summary, this brief review of the fiscal reform being implemented has found much to praise in the package of proposed reforms; it is ambitious and comprehensive, addresses many of the key problems in the existing system of PFM and the measures are well designed to build the foundation for good governance. The quick rollout of legislation and regulations from the State Council has, to date, provided strong support for implementing PFM reforms in the first phase. At the same time, I have also identified some key obstacles to the implementation of these measures. Building a robust system of PFM is only the first (although critical) step in fiscal reform. The key part is yet to come, which is to realign and rationalise the system of intergovernmental fiscal relations, the linchpin of effective management of a large, multilevel fiscal system that has for so long been missing in the Chinese economy. To push through implementation of these critical PFM reforms against fierce headwinds, Minister Lou will need a forceful intervention from the top, and soon, to maintain the current momentum.

\section{References}

Anderlini, J. 2015. 'China orders banks to keep lending to insolvent state projects'. Financial Times, 15 May. Available from: www.ft.com/cms/ s/0/3ec5fea4-faef-11e4-84f3-00144feab7de.html\#ixzz3aw6lymI5 (accessed 11 July 2017). 
Bahl, R., J. Linn and D. Wetzel (eds). 2013. Metropolitan Government Finances in Developing Countries. Cambridge, MA: Lincoln Institute for Land Policy.

Brock, A., H. Wenbin and C. Wong. 2008. 'Free compulsory education: A natural next step after "Two Exceptions and One Subsidy" (TEOS)'. Chinese Education and Society 41(1)(January-February): 87-95.

Han, J., G. Li and H. Yuxin. 2014. 'Deep changes that affect the modernization of the nation's governance system: Minister of Finance Lou Jiwei explains the Overall Program for Deepening Reform of the Fiscal System'. [In Chinese]. Xinhua. Available from: www.mof.gov. cn/zhengwuxinxi/caizhengxinwen/201407/t20140704_1108534. html (accessed 25 July 2017).

International Monetary Fund (IMF). 2014. Government Finance Statistics Manual 2014. Washington, DC: International Monetary Fund.

Lin, W. and C. Wong. 2012. 'Are Beijing's equalization policies reaching the poor? An analysis of direct subsidies under the "Three Rurals" (Sannong)'. China Journal 67(January): 23-46. doi.org/10.1086/ 665738.

Lou, J. 2014. 'Deepening reform of the fiscal and tax system to build a modern system of public finance'. [In Chinese]. Qiushi 2014(20) (13 October).

National Bureau of Statistics of China (NBS). 2014. China Statistical Yearbook. Beijing: China Statistics Press.

National People's Congress (NPC) Standing Committee. 2014. Decision on revising the 'People's Republic of China Budget Law'. [In Chinese]. 31 August. Beijing: National People's Congress of the People's Republic of China. Available from: www.npc.gov.cn/npc/xinwen/2014-09/01/ content_1877061.htm (accessed 11 July 2017).

Naughton, B. 2015. 'Is there a "Xi model" of economic reform? Acceleration of economic reform since fall 2014'. China Leadership Monitor (46)(Winter).

Wong, C. 2005. 'Public sector budgeting issues in China'. In Organisation for Economic Co-operation and Development (OECD) Governance in China. Paris: OECD Publishing. 
Wong, C. 2009. 'Rebuilding government for the 21st century: Can China incrementally reform the public sector?' China Quarterly 200(December): 929-52. doi.org/10.1017/s0305741009990567.

Wong, C. 2010. 'Fiscal reform: Paying for the harmonious society'. China Economic Quarterly 14(2): 22-7.

Wong, C. 2011. 'The fiscal stimulus program and public governance issues in China'. OECD Journal on Budgeting 11(3): 1-22. Paris: OECD Publishing. doi.org/10.1787/budget-11-5kg3nhljqrjl.

Wong, C. 2013a. 'Paying for urbanization: Challenges for China's municipal finance in the 21st century'. In R. Bahl, J. Linn and D. Wetzel (eds) Metropolitan Government Finances in Developing Countries. Cambridge, MA: Lincoln Institute for Land Policy.

Wong, C. 2013b. 'Reforming China's public finances for long-term growth'. In R. Garnaut, C. Fang and L. Song (eds) China: A new model for growth and development. Canberra: ANU E Press. Available from: press.anu.edu.au?p=244991 (accessed 11 July 2017).

Wong, C. and R. Bird. 2008. 'China's fiscal system: A work in progress'. In L. Brandt and T. Rawski (eds) China's Great Transformation: Origins, mechanism and consequences of the post-reform economic boom. New York: Cambridge University Press. doi.org/10.1017/ CBO9780511754234.013.

World Bank. 2007. China: Public services for building the new socialist countryside. Report No. 40221-CN. Washington, DC: The World Bank.

Xinhua. 2013. 'Decision of the Chinese Communist Party Central Committee on several major questions about deepening reform'. [In Chinese]. Xinhua, 15 November. Available from: news.xinhuanet. com/politics/2013-11/15/c_118164235.htm (accessed 11 July 2017). 
This text is taken from Value for Money: Budget and financial management reform in the People's Republic of China, Taiwan and Australia, edited by Andrew Podger, Tsai-tsu Su, John Wanna, Hon S. Chan and Meili Niu, published 2018 by ANU Press, The Australian National University, Canberra, Australia. 